\title{
MASTERING
}

\section{ENGLISH GRAMMAR}


Banking

Basic Management

Biology

British Politics

Business Communication

Chemistry

COBOL Programming

Commerce

Computer Programming

Computers

Data Processing

Economics

Electronics

English Grammar

English Language

English Literature

French

German

\author{
Hairdressing \\ Italian \\ Keyboarding \\ Marketing \\ Mathematics \\ Modern British History \\ Modern World History \\ Nutrition \\ Office Practice \\ Pascal Programming \\ Physics \\ Principles of Accounts \\ Social Welfare \\ Spanish \\ Statistics \\ Study Skills \\ Typewriting Skills \\ Word Processing
}

OTHER BOOKS BY S. H. BURTON INCLUDE

Comprehension Practice

English Study and Composition

Modern Précis Practice

A Comprehensive English Course

People and Communication

Mastering English Language

The Criticism of Poetry

The Criticism of Prose 


\section{MASTERING}

\section{ENGLISH GRAMMAR}

S. H. BURTON

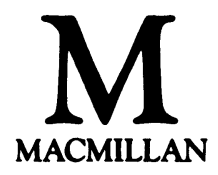


๑) S. H. Burton 1984

All rights reserved. No part of this publication may be reproduced or transmitted, in any form or by any means, without permission

First published 1984 by

MACMILLAN EDUCATION LTD

Houndmills, Basingstoke,

Hampshire, RG21 2XS,

and London

Companies and representatives

throughout the world

British Library Cataloguing in Publication Data

Burton, S. H.

Mastering English grammar.

1. English language - Grammar - 1950-

I. Title

428.2 PE1112

ISBN 978-0-333-36368-3

DOI 10.1007/978-1-349-17519-2 


\section{CONTENTS}

Preface

Acknowledgement

1 What is grammar?

1.1 Language and communication 1

1.2 Making sense

1.3 Grammar and sense

2 Phrases and sentences

2.1 Word groups

2.2 Phrases

2.3 Sentences

2.4 Four kinds of sentences

2.5 The punctuation of written sentences

3 Subject and predicate

4 Words in sentences

5 An introduction to the parts of speech
3.1 The two parts of the sentence 10

3.2 The functions of the two parts 11

3.3 Subject and predicate (1) 12

3.4 Subject and predicate (2) 13

4.1 Words at work

4.2 Different work for the same word

5.1 The eight parts of speech

22

5.2 Nouns 23

5.3 Verbs

25

5.4 Pronouns

29

5.5 Adjectives

30

5.6 Adverbs

33

5.7 Prepositions

38

5.8 Conjunctions

41

5.9 Interjections

42

5.10 Family groups and word behaviour

6 The parts of the simple sentence

6.1 Definition of the simple sentence

6.2 Subject and predicate

6.3 The subject and the subject-word 
6.4 Subject-word and words qualifying subject-word

6.5 Predicate: the verb and words modifying the verb

6.6 Predicate: the direct object 48

6.7 Predicate: the indirect object 50

6.8 Predicate: predicative words (or complement)

6.9 A tabular list of all the parts of the simple sentence

7 Finite verbs and non-finite 7.1 Finite verbs verbs

7.2 Non-finite verbs

7.3 Participial phrases

63

7.4 Gerundive phrases

7.5 Infinitive phrases

8 Simple sentence analysis

8.1 Tabular analysis $\quad 68$

8.2 Descriptive analysis 69

8.3 Graphic analysis 72

8.4 Analysing phrases $\quad 76$

9 Clauses and sentences

9.1 What is a clause? 82

9.2 Main clauses 83

9.3 Co-ordinating conjunctions 83

9.4 Double sentences 83

9.5 Multiple sentences $\quad 85$

9.6 Complex sentences 86

9.7 Kinds of sentences: a check-list 87

9.8 Summing up 88

10 Subordinate clauses and $10.1 \quad$ Introduction 89

the work they do $\quad 10.2$ Adjective-clauses 90

10.3 Adverb-clauses 95

10.4 Noun-clauses $\quad 101$

11 The analysis of complex 11.1 Method 105 double and multiple 11.2 Procedure 106 sentences

11.3 Notes on procedure $\quad 106$

11.4 Worked examples: complex sentences 
11.5 Double and multiple sentence analysis

11.6 Tests in analysis

12 The parts of speech: a

12.1 Introduction

chapter for reference

12.2 Nouns

12.3 Pronouns

12.4 Adjectives

12.5 Verbs

12.6 Adverbs

12.7 Prepositions

12.8 Conjunctions

12.9 Interjections

12.10 'It' as a provisional subject

12.11 'There' as an introductory adverb

13 Common errors and

13.1 Introduction

\section{debatable points}

13.2 Agreement

142

13.3 Case

13.4 Verb-forms

152

13.5 The rule of proximity

13.6 Woolly use of pronouns

13.7 Defining and non-defining phrases and clauses

13.8 Chopping and changing 


\section{PREFACE}

This book is an exploration of the behaviour of English words in English sentences. All the grammatical terms and concepts necessary to a thorough understanding of the simple sentence are first explained and illustrated, for the simple sentence is the bedrock on which fluent, accurate and elegant English expression is based.

Later, the more intricate structures of double, multiple, and complex sentences are examined. Those sentences are enlargements of the simple sentence and they are well made when they conform to its basic patterns.

I must emphasise that Chapter 12 is what it is called: a chapter for reference. It supplies information about grammatical terms that you may need to look up; and it gathers together the facts that are treated at length and in the course of discussion throughout the rest of the book. A source of quick reference is useful, but it is a back-up to, not a substitute for, the expositions given elsewhere.

Grammar cannot explain everything. The English language is living, changing, flexible. Some of its nimble improvisations defy precise explanations. Yet that seems no sound argument for rejecting the very considerable help that grammar can give. I believe that this grammar book will help you as you use the language.

S. H. BURTON 


\section{ACKNOWLEDGEMENT}

The author and publishers are grateful for permission to reproduce cartoons from The Complete Molesworth, copyright $\odot 1958$ by Ronald Searle. 